\title{
Etanercept Inhibits Pro-inflammatory Cytokines Expression in Titanium Particle-Stimulated Peritoneal Macrophages
}

\author{
Zhirong Chen", Liang Zhan", Zhidong Lu1, Yi Ma², Zhihui Gao', Haohui Guo, \\ Long Pang ${ }^{1}$ and Qunhua Jin ${ }^{1 *}$ \\ ${ }^{1}$ Department of Orthopedics, General Hospital of Ningxia Medical University. Yinchuan City, ${ }^{2}$ Department of Pathology and \\ Physiology, Ningxia Medical University. Yinchuan City, 750004, Ningxia, China \\ *For correspondence: Email: jinqunhua@sina.com; Tel: 095-16743581; Fax: 0951-4082981
}

\begin{abstract}
Purpose: To investigate the inhibitory role of Etanercept in pro-inflammatory cytokines such as TNF- $\alpha$, IL-1 $\beta$ and IL-6 production in titanium (Ti) particle stimulated macrophages.

Methods: Peritoneal macrophages were stimulated with $1 \times 10^{9}$ Ti particles and treated simultaneously with or without 10, 100, or $1000 \mathrm{ng} / \mathrm{mL}$ Etanercept. The levels of TNF- $\alpha, I L-1 \beta$ and IL-6 in the culture supernatants were measured using ELISA.

Results: Titanium particles could stimulate TNF- $\alpha, I L-1 \beta$ and IL-6 secretion in peritoneal macrophages. Etanercept inhibited Ti particle-induced TNF- $\alpha$ release by $29.7 \%$ at $10 \mathrm{ng} / \mathrm{ml}(19.19 \pm 4.72 \mathrm{pg} / \mathrm{mL}, p<$ $0.01), 49.3 \%$ at $100 \mathrm{ng} / \mathrm{mL}(13.83 \pm 3.72 \mathrm{pg} / \mathrm{ml}, p<0.01)$ and $60.4 \%$ at $1000 \mathrm{ng} / \mathrm{mL}(10.82 \pm 3.87$ $\mathrm{pg} / \mathrm{mL}, p<0.001)$, IL-1 $\mathrm{k}$ release by $5.23 \%$ at $10 \mathrm{ng} / \mathrm{mL}$ (34.79 $\pm 7.83 \mathrm{pg} / \mathrm{mL}, p>0.05), 21.06 \%$ at 100 $\mathrm{ng} / \mathrm{mL}(28.98 \pm 4.81 \mathrm{pg} / \mathrm{mL}, p<0.01)$ and $29.83 \%$ at $1000 \mathrm{ng} / \mathrm{mL}(25.76 \pm 5.23 \mathrm{pg} / \mathrm{ml}, p<0.001)$, and IL-6 release by $38.69 \%$ at $10 \mathrm{ng} / \mathrm{mL}(256.8 \pm 99.56 \mathrm{pg} / \mathrm{mL}, p<0.01)$, by $42.13 \%$ at $100 \mathrm{ng} / \mathrm{mL}(242.4 \pm$ $33.26 \mathrm{pg} / \mathrm{mL}, p<0.01)$ and $53.4 \%$ at $1000 \mathrm{ng} / \mathrm{ml}(195.2 \pm 48.82 \mathrm{pg} / \mathrm{mL}, p<0.001)$.

Conclusion: Etanercept has potent ability to prevent wear debris-induced osteolysis and may be valuable as a therapeutic agent for the treatment of prosthetic loosening in humans.
\end{abstract}

Keywords: Etanercept; titanium particle; proinflammatory cytokines; peritoneal macrophages

\begin{abstract}
Tropical Journal of Pharmaceutical Research is indexed by Science Citation Index (SciSearch), Scopus, International Pharmaceutical Abstract, Chemical Abstracts, Embase, Index Copernicus, EBSCO, African Index Medicus, JournalSeek, Journal Citation Reports/Science Edition, Directory of Open Access Journals (DOAJ), African Journal Online, Bioline International, Open-J-Gate and Pharmacy Abstracts
\end{abstract}

\section{INTRODUCTION}

Total joint arthroplasties is a widely used final treatment option in many cases to reduce pain, restore joint function and allow patients to return to normal living [1]. Wear debris, which is generated from all the components of the prosthetic joint surface, is widely recognized as the major cause of aseptic loosening $[2,3]$. Wear debris are phagocytosed by macrophages, resulting in the secretion of proinflammatory cytokines, such as tumor necrosis factor- $\alpha$ (TNF- $\alpha)$, interleukin-1 $\beta$ (IL-1 $\beta$ ) and IL-6 [4-6]. Among them, TNF- $\alpha$ is the pivotal cytokine involved in wear debris-induced osteolysis. Blockage of TNF- $\alpha$ activity inhibits both osteoclast differentiation and osteolysis induced by wear particles in the murine calvaria model $[7,8]$. Thus, TNF- $\alpha$ has been proved to be potential treatment target for wear debris induced osteolysis.

Etanercept, which is a soluble fusion protein composed of the extracellular domains of type 2 TNF receptor (p75) fused to the Fc region of a 
$\lg \mathrm{I}_{1}$, is a TNF- $\alpha$ antagonist that has been approved by U.S. F.D.A. for the treatment of rheumatoid, juvenile rheumatoid and psoriatic arthritis [9,10]. Recent clinical data have indicated that Etanercept also has beneficial effects on preventing bone erosions in rheumatoid arthritis and psoriasis [11,12]. Given the emerging evidence that TNF- $\alpha$ plays a similar and central pathogenetic role in prosthetic loosening and rheumatoid arthritis, we proposed that Etanercept has the ability to inhibit wear debris induced osteolysis. The objective of current study was to determine if Etanercept was capable of inhibiting pro-inflammatory cytokines such as TNF- $\alpha, I L-1 \beta$ and IL- 6 production in titanium (Ti) particle stimulated macrophages.

\section{EXPERIMENTAL}

\section{Animals and reagents}

BALB/c mice (6 - 8 weeks old) were purchased from laboratory animal center of Ningxia medical college (Ningxia, China) and maintained in a temperature controlled room with $12 \mathrm{~h}$ light /dark cycles with regular chow and water. The experimental procedures were approved by the Laboratory Animal Care Committee at Ningxia medical college. All animals received humane care according to the criteria outlined in the "Guide for the Care and Use of Laboratory Animals" prepared by the National Academy of Sciences and published by the National Institutes of Health (NIH publication 86 - 23 revised 1985). Etanercept (trade name Enbrel) was purchased from Amgen \& Wyeth (Philadelphia, PA, USA). Titanium particles (Ti6AI4V alloy) were a gift from Zimmer (Warsaw, IN, USA). Mouse tumor necrosis factor- $\alpha$ (TNF- $\alpha)$, interleukin $-1 \beta$ (IL-1 $\beta$ ) and interleukin-6 (IL-6) ELISA kit were from R\&D Systems (Minneapolis, MN, USA). RPMI-1640, L-glutamine, penicillin, streptomycin, and fetal bovine serum (FBS) were from Gibco (Grand Island, NY, USA). Limulus assay kit was from Horseshoe Crab Reagent Manufactory (Xiamen, China).

\section{Mouse peritoneal macrophage culture}

Resident peritoneal macrophages were collected from mice as previously described [13]. Briefly, peritoneal macrophages were recovered by peritoneal lavage with $5 \mathrm{ml}$ of cold RPMI-1640 medium and isolated by centrifugation (1000 $\mathrm{rpm} / \mathrm{min}, 10 \mathrm{~min})$. Cells $\left(2 \times 10^{5}\right)$ were plated on 24-well tissue culture plates and cultured in RPMI 1640 medium containing $10 \%$ FBS, penicillin $(100 \mathrm{U} / \mathrm{ml})$ and streptomycin (100 $\mathrm{U} / \mathrm{mL})$ at $37{ }^{\circ} \mathrm{C}, 5 \% \mathrm{CO}_{2}$ for $12 \mathrm{~h}$. The no adherent cells were removed, and the adherent cells were washed twice with RPMI-1640 medium and used in experiments.

\section{Preparation of Ti particles}

Commercially pure Titanium (Ti) particles (Zimmer, Warsaw, USA) were sterilized by incubation in $25 \%$ nitric acid at $70{ }^{\circ} \mathrm{C}$ for $1 \mathrm{~h}$ and then suspended in phosphate-buffered saline (PBS) at a concentration of $1 \times 10^{9}$ particles $/ \mathrm{ml}$ [8]. Particle size was confirmed with a Coulter Channelizer (Beckman Coulter, Fullerton, CA, USA), which determined $95 \%$ of the particles to be $<5 \mu \mathrm{m}$ in diameter.

\section{Limulus amebocyte lysate assay}

For determination of endotoxin concentration in Ti particle suspension, limulus amebocyte lysate (LAL) assays were performed according to the manufacturer's protocol. Briefly, Ti particles suspension serum samples were diluted $10 \%$ (v/v) in LAL reagent water, and heated to $70{ }^{\circ} \mathrm{C}$ for $5 \mathrm{~min}$ to remove any nonspecific inhibition to the assay. Samples were incubated with equal volumes of $\mathrm{LAL}$ for $10 \mathrm{~min}$ at $37^{\circ} \mathrm{C}$ and developed with equal volumes of substrate solution for $6 \mathrm{~min}$. The absorbance of the assay plate was read at $405 \mathrm{~nm}$ using a micro plate reader (BioTek, Winooski, VT). Samples and standards were run in duplicate, and the detection limit was $0.15 \mathrm{EU} / \mathrm{mL}$.

\section{ELISA}

Peritoneal macrophage at $1 \times 10^{5}$ cells/well were stimulated with $1 \times 10^{9} \mathrm{Ti}$ particles and treated simultaneously with or without 10,100 , or 1000 $\mathrm{ng} / \mathrm{mL}$ Etanercept. After $18 \mathrm{~h}$, culture supernatants were collected and centrifuged at $1500 \mathrm{rpm}$ for $5 \mathrm{~min}$ to remove the Ti particles and cells, the supernatants were collected, and the levels of TNF- $\alpha, I L-1 \beta$ and IL- 6 in the culture were measured using ELISA kits (R\&D Systems, Minneapolis, MN, USA) according to the manufacturer's instructions.

\section{Statistics}

All data were analyzed by Student's t test and were expressed as means \pm SEM, differences were considered statistically significant when $p<$ 0.05 . The significance levels are marked ${ }^{*} p<$ $0.05 ;{ }^{* *} p<0.01 ;{ }^{* * *} p<0.001$.

\section{RESULTS}

It has been shown that particulate debris could stimulate the production of pro-inflammatory 
cytokines such as TNF- $\alpha$, IL- $1 \beta$ and IL-6 in macrophages $[14,15]$. We first determined the effect of Ti particles that induces TNF- $\alpha$, IL-1 $\beta$ and IL-6 release in resident peritoneal macrophages. Limulus assay has been performed and data showed that the Ti particle suspension was free of endotoxin $<0.25$ $\mathrm{EU} / \mathrm{mL}$ ). $1 \times 10^{9} \mathrm{Ti}$ particles were then used to treat macrophages and TNF- $\alpha, \mathrm{IL}-1 \beta$ and IL-6 production were measured by ELISA. Data showed that TNF- $\alpha(9.48 \pm 1.58 \mathrm{pg} / \mathrm{mL}$ vs. $27.3 \pm$ $4.47 \mathrm{pg} / \mathrm{mL}, p<0.001)$, IL-1ß $(24.25 \pm 5.25$ $\mathrm{pg} / \mathrm{mL}$ vs. $36.71 \pm 7.57 \mathrm{pg} / \mathrm{mL}, p<0.01)$ and IL-6 $(122.3 \pm 37.78 \mathrm{pg} / \mathrm{mL}$ vs. $418.9 \pm 31.98 \mathrm{pg} / \mathrm{mL}$, $p<0.001)$ production was substantially induced by $\mathrm{Ti}$ particles (Fig. $1 \mathrm{~A}-\mathrm{C}$ ). To evaluate the inhibitory effect of Etanercept on $\mathrm{Ti}$ particleinduced TNF- $\alpha, \quad$ IL-1 $\beta$ and IL- 6 release, peritoneal macrophages were treated with or without Etanercept $(10,100$, or $1000 \mathrm{ng} / \mathrm{mL}$ ) for $18 \mathrm{~h}$. Data showed that Etanercept significantly inhibited $\mathrm{Ti}$ particle-induced TNF- $\alpha$ release by $29.7 \%$ at $10 \mathrm{ng} / \mathrm{mL}(19.19 \pm 4.72 \mathrm{pg} / \mathrm{ml}, p<$ $0.01), 49.3 \%$ at $100 \mathrm{ng} / \mathrm{mL}$.

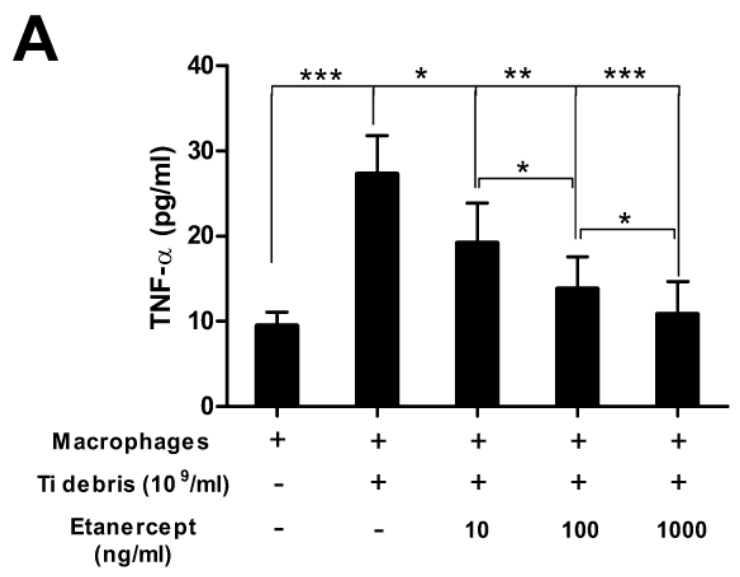

B

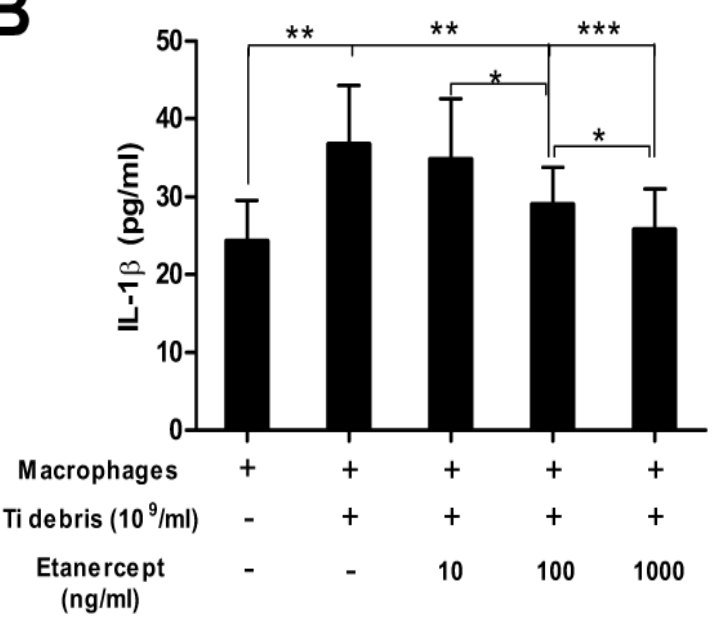

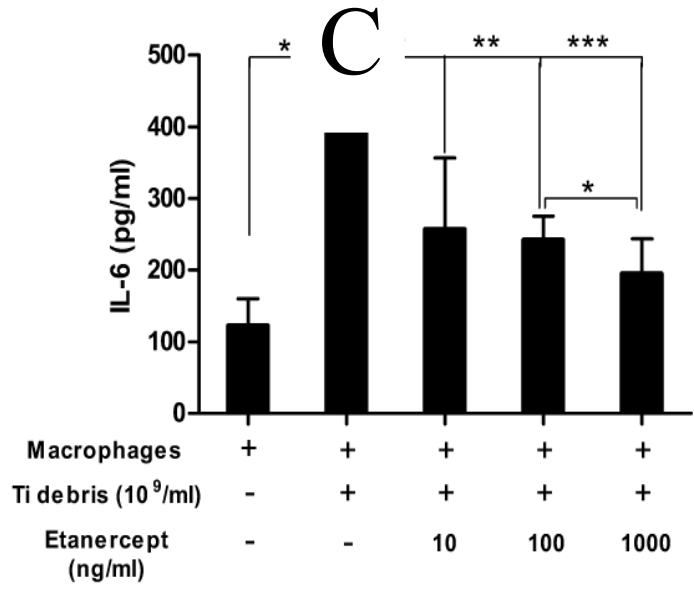

Figure 1: Inhibitory effect of Etanercept on titanium particle-induced TNF- $\alpha, \mathrm{IL}-1 \beta$ and IL- 6 release by macrophages. Peritoneal macrophage $\left(1 \times 10^{5}\right.$ cells/well) were stimulated with $1 \times 10^{9} \mathrm{Ti}$ particles and treated simultaneously with or without 10,100 , or 1000 $\mathrm{ng} / \mathrm{mL}$ Etanercept. After $18 \mathrm{~h}$, culture supernatants were collected and centrifuged at $1500 \mathrm{rpm}$ for $5 \mathrm{~min}$ to remove the Ti particles and cells, the supernatants were collected, and the levels of TNF- $\alpha(A), I L-1 \beta$ (B) and IL-6 $(C)$ in the culture were measured using ELISA kits. The data shown are representatives of three independent experiments. Data are shown as mean $\pm \operatorname{SEM}\left({ }^{*} p<0.05,{ }^{* *} p<0.01,{ }^{* * *} p<0.001\right)$

$(13.83 \pm 3.72 \mathrm{pg} / \mathrm{mL}, p<0.01)$ and $60.4 \%$ at $1000 \mathrm{ng} / \mathrm{mL}(10.82 \pm 3.87 \mathrm{pg} / \mathrm{mL}, p<0.001)$ compared to the $\mathrm{Ti}$ particles stimulated control $(27.3 \pm 4.47 \mathrm{pg} / \mathrm{mL})($ Fig.1 A), and significantly inhibited $\mathrm{Ti}$ particle-induced IL-1 $\beta$ release by $5.23 \%$ at $10 \mathrm{ng} / \mathrm{mL}(34.79 \pm 7.83 \mathrm{pg} / \mathrm{mL}, p>$ $0.05), 21.06 \%$ at $100 \mathrm{ng} / \mathrm{mL}(28.98 \pm 4.81$ $\mathrm{pg} / \mathrm{mL}, p<0.01)$ and $29.83 \%$ at $1000 \mathrm{ng} / \mathrm{ml}$ $(25.76 \pm 5.23 \mathrm{pg} / \mathrm{mL}, p<0.001)$ compared to the $\mathrm{Ti}$ particles stimulated control $(36.71 \pm 7.57$ $\mathrm{pg} / \mathrm{mL}$ ) (Fig. 1B). Etanercept could also significantly inhibit $\mathrm{Ti}$ particle-induced IL-6 release by $38.69 \%$ at $10 \mathrm{ng} / \mathrm{mL}(256.8 \pm 99.56$ $\mathrm{pg} / \mathrm{mL}, p<0.01), 42.13 \%$ at $100 \mathrm{ng} / \mathrm{mL}(242.4 \pm$ $33.26 \mathrm{pg} / \mathrm{mL}, p<0.01)$ and $53.4 \%$ at 1000 $\mathrm{ng} / \mathrm{mL}(195.2 \pm 48.82 \mathrm{pg} / \mathrm{mL}, \quad p<0.001)$ compared to the Ti particles stimulated control $(418.9 \pm 31.98 \mathrm{pg} / \mathrm{mL})$ (Fig. 1C). These results demonstrate that Etanercept has a dosedependent inhibitory effect on Ti particle-induced pro-inflammatory cytokines such as TNF- $\alpha$, IL-1 $\beta$ and IL-6 production in macrophages.

\section{DISCUSSION}

The major finding of this study is that Etanercept, a TNF- $\alpha$ antagonist, could dose-dependently inhibit the production of TNF- $\alpha$, IL- $1 \beta$ and IL- 6 by 
macrophages stimulated with Ti particles. TNF- $\alpha$ may be a dominant upstream event that has dramatic consequences on periprosthetic osteolysis, because blockade of TNF- $\alpha$ also reduces the secretion of IL-1 $\beta$ and IL-6, TNF- $\alpha$ acts as an autocrine/paracrine stimulator of additional TNF- $\alpha$ release. These results are consistent with our hypothesis that Etanercept can inhibit the pro-inflammatory cytokine cascade induced by $\mathrm{Ti}$ stimulation of macrophages. Similar results were recently published by other investigators examining the effects of Etanercept on wear debris induced osteolysis using macrophage cell lines [16]. Combined with previously reports, It suggests that TNF- $\alpha$ is critically involved in osteolysis and aseptic loosening and that soluble TNF-a inhibitors, such as Etanercept, may be useful as therapeutic agents for the treatment of prosthetic loosening.

TNF- $\alpha$ expression has been studied extensively in response to various stimuli. In this study, we used Ti particles to stimulate a pro-inflammatory response in macrophage cultures in vitro. $\mathrm{Ti}$ particles are readily available and the majority of the particles are small enough to be phagocytosed by macrophages (< $10 \mu \mathrm{m}$ in diameter) [17]. Meanwhile, numerous literatures have shown that $\mathrm{Ti}$ particles induce the same reaction as other types of implant wear debris [18].

Macrophages play a crucial role in inflammatory bone disorder such as wear debris-induced aseptic loosening and are major sources of inflammatory mediators. Here we chose resident peritoneal macrophages, which have been widely used as a macrophage source in mice as the exposed cells. Previous studies of macrophage physiology customarily used macrophage cell lines such as RAW264.7 and J774 cells [19]. These cells, derived from pristane-elicited murine peritoneal macrophages transformed with Abelson leukemia virus, have been particularly valuable because of their ease of culture, rapid growth rate, and phenotypic resemblance to primary macrophages. However, these cell lines cannot fully mimic the phenotype of primary macrophages in vivo and the uptake efficiency of $\mathrm{Ti}$ particles by the peritoneal macrophages maybe higher than that of RAW264.7 cells.

Although we have shown that Etanercept is able to prevent pro-inflammatory cytokines production by macrophages stimulated with wear debris, the precise mechanism by which Etanercept is involved in wear debris induced osteolysis remains unknown. As the first pro-inflammatory cytokine produced by macrophages in response to particles, TNF- $\alpha$ has been shown to control the release of other pro-inflammatory mediators such IL-1 $\beta$ and IL-6. One primary mechanism may be that, as soluble receptor of TNF, Etanercept can competitively bind to the TNF membrane receptor (mTNF-R) on the cell surface and block all signaling through the membrane bound TNF receptors, thus inhibiting osteoclastogenesis and osteoclast activity. Another important mechanism by which TNF- $\alpha$ contributes to the pathogenesis of aseptic loosening is its inhibitory effects on osteoblasts. Etanercept may inhibit osteoclastogenesis by down regulating the expression of osteoprotegerin ligand and M-CSF, IL-6 and PEG2 in osteoblastic cells [20].

\section{CONCLUSION}

In summary, the present study suggests that Etanercept inhibits Ti particle-induced TNF-a, IL$1 \beta$ and IL-6 release by macrophages, and therefore, may be a potential therapeutic agent for the prevention and/or treatment of osteolysis and loosening after TJA. Further investigations are required to examine the inhibitory effects of Etanercept on wear debris induced osteolysis in vivo and the underlying molecular mechanism.

\section{REFERENCES}

1. Harris WH. The problem is osteolysis. Clin Orthop Relat Res 1995: 46-53.

2. Harris WH. Wear and periprosthetic osteolysis: the problem. Clin Orthop Relat Res 2001: 66-70.

3. Saleh KJ, Thongtrangan I and Schwarz EM. Osteolysis: medical and surgical approaches. Clin Orthop Relat Res 2004: 138-147.

4. Ragab AA, Van De Motter R, Lavish SA, Goldberg VM, Ninomiya JT, Carlin $C R$ and Greenfield EM. Measurement and removal of adherent endotoxin from titanium particles and implant surfaces. $J$ Orthop Res 1999; 17: 803-809.

5. Blaine TA, Pollice PF, Rosier RN, Reynolds PR, Puzas $J E$ and O'Keefe RJ. Modulation of the production of cytokines in titanium-stimulated human peripheral blood monocytes by pharmacological agents. The role of cAMP-mediated signaling mechanisms. J Bone Joint Surg Am 1997; 79: 1519-1528.

6. Goodman SB, Huie $P$, Song $Y$, Schurman D, Maloney $W$, Woolson $S$ and Sibley $R$. Cellular profile and cytokine production at prosthetic interfaces. Study of tissues retrieved from revised hip and knee replacements. $J$ Bone Joint Surg Br 1998; 80: 531-539.

7. Childs LM, Goater JJ, O'Keefe RJ and Schwarz EM. Effect of anti-tumor necrosis factor-alpha gene therapy on wear debris-induced osteolysis. J Bone Joint Surg Am 2001; 83-A: 1789-1797. 
8. Childs LM, Goater JJ, O'Keefe RJ and Schwarz EM. Efficacy of etanercept for wear debris-induced osteolysis. J Bone Miner Res 2001; 16: 338-347.

9. Skolnick AA. Biological response modifiers may yield a new class of drugs to treat arthritis. JAMA 1997; 277: 276-278.

10. Feldmann $M$ and Maini RN. Lasker Clinical Medical Research Award. TNF defined as a therapeutic target for rheumatoid arthritis and other autoimmune diseases. Nat Med 2003; 9: 1245-1250.

11. Lisbona M, Maymo J, Solano A, Almirall M, Navallas $M$, Ares $\mathrm{J}$ and Carbonell $\mathrm{J}$. Repair of erosions in patients with rheumatoid arthritis treated with etanercept: magnetic resonance imaging findings after 1 year of follow-up. Scand J Rheumatol 2013; 42: 437-444.

12. Papp KA, Tyring S, Lahfa M, Prinz J, Griffiths CE, Nakanishi $A M$, Zitnik $R$, van de Kerkhof $P C$ and Melvin L. A global phase III randomized controlled trial of etanercept in psoriasis: safety, efficacy, and effect of dose reduction. $\mathrm{Br} J$ Dermatol 2005; 152: 1304-1312.

13. Schon-Hegrad MA and Holt PG. Improved method for the isolation of purified mouse peritoneal macrophages. $J$ Immunol Methods 1981; 43: 169-173.

14. Nakashima Y, Sun DH, Trindade MC, Maloney WJ, Goodman SB, Schurman DJ and Smith RL. Signaling pathways for tumor necrosis factor-alpha and interleukin-6 expression in human macrophages exposed to titanium-alloy particulate debris in vitro. $J$ Bone Joint Surg Am 1999; 81: 603-615.
15. Caicedo MS, Desai R, McAllister K, Reddy A, Jacobs JJ and Hallab NJ. Soluble and particulate Co-Cr-Mo alloy implant metals activate the inflammasome danger signaling pathway in human macrophages: a novel mechanism for implant debris reactivity. J Orthop Res 2009; 27: 847-854.

16. Schwarz EM, Campbell D, Totterman S, Boyd A, O'Keefe $R J$ and Looney RJ. Use of volumetric computerized tomography as a primary outcome measure to evaluate drug efficacy in the prevention of periprosthetic osteolysis: a 1-year clinical pilot of etanercept vs. placebo. J Orthop Res 2003; 21: 10491055.

17. Braun V, Fraisier V, Raposo G, Hurbain I, Sibarita JB, Chavrier P, Galli $T$ and Niedergang F. TIVAMPNAMP7 is required for optimal phagocytosis of opsonised particles in macrophages. EMBO J 2004; 23: 4166-4176.

18. Engh CA Jr, Moore KD, Vinh TN and Engh GA. Titanium prosthetic wear debris in remote bone marrow. A report of two cases. J Bone Joint Surg Am 1997; 79: 1721-1725.

19. Jin S, Park JY, Hong JM, Kim TH, Shin HI, Park EK and Kim SY. Inhibitory effect of (-)-epigallocatechin gallate on titanium particle-induced TNF-alpha release and in vivo osteolysis. Exp Mol Med 2011; 43: 411-418.

20. Kwan Tat S, Padrines M, Theoleyre S, Heymann $D$ and Fortun Y. IL-6, RANKL, TNF-alpha/IL-1: interrelations in bone resorption pathophysiology. Cytokine Growth Factor Rev 2004; 15: 49-60. 